\title{
Percutaneous Balloon Angioplasty for Aortic Coarctation in Newborns and Infants: Is It Still an Option?
}

\author{
Shehla Jadoon, $\mathrm{MRCPCH}{ }^{1}$, Milad El-Segaier, MD, PhD ${ }^{1,2}$, Mohammed Omar Galal, MD, PhD, MBA ${ }^{3,4^{*}}$ \\ ${ }^{1}$ Department of Pediatric Cardiology, King Fahad Medical City, King Salman Heart Center, Riyadh, Saudi Arabia \\ ${ }^{2}$ Department of Pediatric Cardiology, Skåne University Hospital, Lund, Sweden \\ ${ }^{3}$ Department of Pediatric Cardiology, Essen University, Essen, Germany \\ ${ }^{4}$ Department of Pediatric Cardiology, King Faisal Specialist Hospital and Research Center, Jeddah, Saudi Arabia
}

\begin{abstract}
Background: Coarctation of aorta may present as severe heart failure in infants and may lead to myocardial dysfunction. Current evidence supports surgical management of neonatal coarctation; however, it can be precarious in sick infants. Thus, percutaneous balloon angioplasty may be a beneficial alternative palliation before possible surgical treatment.

Methods: To investigate the safety, efficacy, immediate, and mid-term outcome of percutaneous balloon angioplasty for aortic coarctation in infants who present late and have additional risk factors for surgical treatment, a retrospective case series was examined, reviewing the charts of all patients under six months of age who underwent balloon angioplasty for aortic coarctation. Results: Between January 2008 and April 2014, 14 infants with coarctation were included. Their mean weight was $3.5 \mathrm{~kg}(1.9-5 \mathrm{~kg})$ and they had a mean age of 69 days (4-142 days). All patients were sick, needed admission in an intensive care unit for inotropic and/or ventilator support, and had different additional risk factors for surgery. All underwent successful percutaneous balloon angioplasty with minor complications. Following which their clinical condition and left ventricular function improved leading to weaning from inotrope and ventilator support. On further follow up, seven underwent elective surgical repair, two needed re-dilation, and three continued without any further intervention.
\end{abstract}

Fax +1 2037853346

E-Mail: jshd@scienceinternational.org

http://structuralheartdisease.org/
(C) 2016 Journal of Structural Heart Disease Published by Science International Corp.

Accessible online at: http://structuralheartdisease.org/ ISSN 2326-4004
Conclusions: Surgical repair for native neonatal and infantile coarctation is a preferred choice of treatment, but it can be challenging in sick patients with additional risk factors. However, percutaneous balloon angioplasty remains a safe and effective temporary palliation. Despite a high incidence of restenosis, some patients do not need mid-term further intervention.

Copyright @ 2016 Science International Corp.

\section{Key Words}

Neonates - Infants - Balloon dilation - Aortic coarctation - Percutaneous balloon angioplasty

\section{Introduction}

Coarctation of aorta (CoA) accounts for $5-7 \%$ of all congenital heart diseases $[1,2]$. Native CoA in infancy may present with symptoms of congestive heart failure, low cardiac output, and/or shock. Since introduction, four decades ago, the role of percutaneous balloon angioplasty in this age group remains controversial [3-5].

It is accepted that surgical repair is the preferred treatment for neonatal and infancy CoA. One of the most important arguments being that percutaneous balloon angioplasty in the first months of life has an extremely high re-stenosis rate $[6,7]$. 
In certain circumstances, such as low body weight, critical patient condition with severe myocardial dysfunction and/or other organ failure, surgical repair is not preferable [8-10]. Additional risk factors like late presentation or other systemic disease may influence treatment option decisions. Under these conditions, whilst acknowledging that percutaneous balloon angioplasty is associated with high re-stenosis rate and possible aneurysm formation [5, 11, 12], it is argued that it can provide short to midterm solutions for stabilization of patients allowing surgical repair to be performed later with less risks.

The aim of this study was to present our experience with balloon angioplasty in neonates and infants with aortic coarctation who were referred late to us and/ or had confounding risk factors precluding surgical treatment. Additionally, we were evaluating the immediate and mid-term outcome of this procedure in our patient population.

\section{Methods}

A retrospective cohort study was performed between January 2008 and April 2014 Fourteen neonates and infants (age less than 6 months) who underwent balloon angioplasty for aortic coarctation were identified and included in the study. All patients were admitted in an intensive care unit either due to need of respiratory support or poor cardiac output state. Additionally, they had different confounding factors which might have increased their risk of surgical treatment. Ethical clearance and permission to publish the related clinical information was obtained from the hospitals institutional review board (IRB).

\section{Inclusion Criteria}

All patients less than 6 months of age who presented with hemodynamic instability (low cardiac output) and/or any additional risk factors which may have increased their risk of surgery were included. The additional risk factors which were considered were: Late referral combined with no improvement to medical therapy, low body weight, long ventilator support, chronic lung disease, and serious systemic disease.

\section{Exclusion Criteria}

Patients less than 6 months of age, who showed stable hemodynamics with good cardiac output and no additional risk factors for surgical treatment. These patients were sent electively to surgery.

Patients underwent clinical and complete echocardiography evaluation before and after the percutaneous balloon an- gioplasty and at follow up. The following echocardiographic factors were evaluated: Doppler gradient across the segment of coarctation, existence of diastolic run off, patency of arterial duct, right and left ventricular cardiac function and diameters, any associated cardiac lesion, aortic arch dimensions (proximal arch, transverse arch between first branch and left common carotid artery, and distal arch between left common carotid and subclavian arteries, narrowest segment), associated mitral valve involvement, and any left ventricular outflow obstruction.

\section{Procedure Details}

Percutaneous balloon angioplasty was performed in all patients. During procedure patients received heparin boluses to keep activated clotting time (ACT) more than 200 seconds. After establishing an arterial access with a 4-Fr sheath in the majority of patients (more recently a $3-\mathrm{Fr}$ sheath had been utilized in two patients), a pigtail catheter (Medtronic, Minneapolis, Minnesota, USA) was advanced into the descending and ascending aorta. The pressures across the isthmus were measured. The aortogram in lateral and antero-posterior projection was performed. The transverse arch, the isthmus distal to the left subclavian artery and narrowest diameter were measured. Percutaneous transluminal coronary angioplasty (PTCA) balloon of different sizes and lengths were used for intervention in most cases (Medtronic, Minneapolis, Minnesota, USA). Balloon size was chosen according to aortic size immediately above the stenosis and was one $\mathrm{mm}$ smaller than this diameter. The balloon was usually inflated three-four times across the narrowest region. Pressures after the procedure were obtained, making sure not to cross the dilated region a second time with the wire. Repeat aortogram was performed to document the angiographic results of the intervention. To avoid aortic wall injury, the pigtail catheter used for angiogram was advanced and withdrawn over a wire through the dilated segment.

\section{Results}

In 14 patients ( 3 female, 11 male), their mean weight was $3.5 \mathrm{~kg}(1.9-5 \mathrm{~kg})$ and their mean age was 69 days (4-142 days) (Table 1 ).

\section{Risk Factors for Surgical Treatment}

Risk factors for surgical treatment for each patient are presented in Table 2. Many patients showed no improvement despite medical therapy including inotropes and prostaglandin $\mathrm{E}_{1}\left(\mathrm{PGE}_{1}\right)$. Another risk factor was low body weight especially for those born premature where we had to delay the intervention whilst awaiting their growth. Additionally some patients were referred late, some were on ventilation 
Table 1: Demographic and clinical data of patients.

\begin{tabular}{|c|c|c|c|c|c|c|c|c|}
\hline \multirow{2}{*}{$\begin{array}{l}\text { Age } \\
\text { (days) }\end{array}$} & \multirow[b]{2}{*}{ Gender } & \multirow{2}{*}{$\begin{array}{l}\text { Weight } \\
\text { (kg) }\end{array}$} & \multicolumn{2}{|c|}{ Urine output (ml/kg/hr) } & \multirow{2}{*}{$\begin{array}{l}\mathrm{PGE}_{1} \\
\text { before }\end{array}$} & \multirow[b]{2}{*}{ Ventilator mode } & \multirow{2}{*}{$\begin{array}{l}\text { Duration of respiratory } \\
\text { support before PBA }\end{array}$} & \multirow{2}{*}{$\begin{array}{l}\text { Inotropes } \\
\text { support }\end{array}$} \\
\hline & & & before & after & & & & \\
\hline 62 & M & 3.5 & 1.2 & 4.8 & $\mathrm{~N}$ & MV & 58 & $\mathrm{~N}$ \\
\hline 20 & M & 4 & 1.7 & 3.4 & Y & None & N & $\mathrm{N}$ \\
\hline 132 & $\mathrm{~F}$ & 3.4 & 1.5 & 3.1 & N & MV & 91 & N \\
\hline 12 & $\mathrm{~F}$ & 2.4 & 0.6 & 2.3 & N & MV & 12 & Y \\
\hline 4 & $F$ & 1.9 & 2.1 & 3.1 & Y & CPAP & 2 & N \\
\hline 124 & M & 4.3 & 1.1 & 1.4 & N & MV & 5 & Y \\
\hline 142 & M & 5 & 1.3 & 2.9 & N & MV & 62 & N \\
\hline 64 & M & 4 & 0.9 & 2.8 & N & Oxygen via NC & 3 & Y \\
\hline 24 & M & 3.7 & 2.7 & 3.6 & Y & None & N & N \\
\hline 65 & M & 4.5 & 0.8 & 2.5 & N & MV & 22 & Y \\
\hline 94 & M & 3.1 & 1.3 & 3.2 & N & MV & 53 & N \\
\hline 103 & M & 4.5 & 2.1 & 2.7 & N & Oxygen via NC & 6 & N \\
\hline 46 & M & 2.1 & 2.7 & 4.3 & Y & Oxygen via NC & 4 & N \\
\hline 82 & M & 2.7 & 2.1 & 3.3 & Y & Oxygen via NC & 3 & $\mathrm{~N}$ \\
\hline
\end{tabular}

$\mathrm{PGE}_{1}=$ prostaglandin $\mathrm{E}_{1} ; \mathrm{M}=$ male; $\mathrm{F}=$ female; $\mathrm{N}=$ none; $\mathrm{Y}=\mathrm{yes} ; \mathrm{MV}=$ mechanical ventilation; $\mathrm{CPAP}=$ continuous positive airway pressure; $\mathrm{NC}=$ nasal cannula; PBA = percutaneous balloon angioplasty.

for a long time and some had chronic or systemic disease.

\section{Associated Cardiac Lesions}

Associated cardiac lesions and echocardiographic findings at presentation for each patient are presented in Table 2. Two thirds of the patients had moderate to severe right ventricular dilatation. Half of the patients had patent arterial duct, and few had hypoplasia of arch. One third of patients had large significant ventricular septal defects. Other associated cardiac lesions were double orifice mitral valve in one patient and severe aortic valve stenosis in another

\section{Immediate Outcome after Balloon Dilation}

Mean fluoroscopy time was 15.3 minutes (range 2-62 min), and procedure time (skin-to-skin) was 72 minutes (range 34-174 min). Two patients needed transfusion due to blood loss during procedure. Four patients had cold leg with absent pulses and were treat- ed with heparin infusion for 48 hours which resulted in an improvement (these were not the infants who were cannulated with a 3-Fr sheath). The mean gradient across the coarctation dropped from 37 (range 6-90 $\mathrm{mm} \mathrm{Hg}$ ) to $14 \mathrm{~mm} \mathrm{Hg}$ (range $0-40 \mathrm{~mm} \mathrm{Hg}$ ). The drop was of clinical relevance and statistically significant $(p<0.0024,95 \%$ confidence interval 9.02-37.41). Detailed catheterization data are presented in Table 3.

\section{Hospital Course until Discharge}

All patients were weaned off ventilation or oxygen supplement within 72 hours after intervention, except two who continued to need support for six days. Before the procedure, four patients required inotrope support and five patients were on prostaglandin. Prostaglandin was stopped in all five patients within 48 hours of intervention. Two patients needed inotropes for a longer period of time (more than 48 hours) and ventilator support due to sepsis (Pseudomonas aeruginosa and Staphylococcus in blood culture). 
Table 2: indication criteria for ballooning and echocardiography finding of all patients at presentation.

\begin{tabular}{|c|c|c|c|c|c|c|c|}
\hline \multirow[b]{2}{*}{ Associated cardiac lesions } & \multirow{2}{*}{$\begin{array}{l}\text { Risk factors for surgical } \\
\text { treatment }\end{array}$} & \multirow{2}{*}{$\begin{array}{l}\text { Presence of } \\
\text { PDA }\end{array}$} & \multirow{2}{*}{$\begin{array}{l}\text { RV dilatation } \\
\text { (function) }\end{array}$} & \multicolumn{4}{|c|}{ Aorta dimensions } \\
\hline & & & & AA & TA & DA & Isthmus \\
\hline Discrete coarctation & Prolonged ventilation & Moderate & $\begin{array}{l}\text { Severe } \\
\text { (good) }\end{array}$ & 7.2 & 6.6 & 4.6 & 2.9 \\
\hline $\begin{array}{l}\text { Discrete coarctation, moderate ASD, } \\
\text { large apical VSD }\end{array}$ & $\begin{array}{l}\text { No response to medical } \\
\text { therapy, large apical VSD }\end{array}$ & None & $\begin{array}{l}\text { Mild } \\
\text { (good) }\end{array}$ & 7.5 & 7.1 & 3.1 & 2.7 \\
\hline $\begin{array}{l}\text { Discrete coarctation, double orifice } \\
\text { MV, } \\
\text { subaortic membrane }\end{array}$ & $\begin{array}{l}\text { Late referral, SCD, prolonged } \\
\text { ventilation ( } 130 \text { days), CLD }\end{array}$ & Large & $\begin{array}{l}\text { Normal, RVH } \\
\text { (good) }\end{array}$ & 10 & 6.6 & 4.3 & 2.0 \\
\hline $\begin{array}{l}\text { Long segment coarctation, } \\
\text { large unrestrictive inlet membranous } \\
\text { VSD, mitral stenosis }\end{array}$ & $\begin{array}{l}\text { Post-surgical arch reconstruction, } \\
\text { poor myocardial function }\end{array}$ & Tiny & $\begin{array}{l}\text { Mild, RVH } \\
\text { (good) }\end{array}$ & 6.4 & 2.5 & 2.4 & 2.1 \\
\hline $\begin{array}{l}\text { Discrete coarctation, ASD } \\
\text { secundum, } \\
\text { large VSD }\end{array}$ & $\begin{array}{l}\text { Low body weight associated } \\
\text { with arch hypoplasia }\end{array}$ & Large & $\begin{array}{l}\text { Mild } \\
\text { (good) }\end{array}$ & 5.7 & 3.1 & 2.3 & 1.4 \\
\hline Discrete coarctation & $\begin{array}{l}\text { RSV infection, poor myocardial } \\
\text { function, no improvement with } \\
\text { medical therapy }\end{array}$ & None & $\begin{array}{l}\text { Normal } \\
\text { (good) }\end{array}$ & 10 & 5 & 3.2 & 1.2 \\
\hline $\begin{array}{l}\text { Discrete coarctation, } \\
\text { moderate ASD }\end{array}$ & $\begin{array}{l}\text { Late referral, CLD, dysmorphism, } \\
\text { severe pharyngeal dysphagia. }\end{array}$ & Small & $\begin{array}{l}\text { Moderate } \\
\text { (good) }\end{array}$ & 7 & 6 & 4.8 & 2.6 \\
\hline Discrete coarctation & $\begin{array}{l}\text { Low cardiac output despite } \\
\text { medical therapy }\end{array}$ & None & $\begin{array}{l}\text { Mild } \\
\text { (good) }\end{array}$ & 7.8 & 5.6 & 6 & 1.8 \\
\hline Discrete coarctation & $\begin{array}{l}\text { Poor myocardial function, no } \\
\text { response to medical therapy }\end{array}$ & None & $\begin{array}{l}\text { Mild, RVH } \\
\text { (good) }\end{array}$ & 10 & 3.7 & 4.3 & 2.2 \\
\hline $\begin{array}{l}\text { Tight coarctation, } \\
\text { bicuspid AoV with stenosis, } \\
\text { ASD secundum }\end{array}$ & $\begin{array}{l}\text { Prolonged ventilation, severe } \\
\text { AoV stenosis, poor myocardial } \\
\text { function despite prolong ino- } \\
\text { tropes, (underwent dilatation } \\
\text { for AoV, CoA) }\end{array}$ & None & $\begin{array}{l}\text { Normal } \\
\text { (good) }\end{array}$ & 7.3 & 3.3 & 3.0 & 1.7 \\
\hline $\begin{array}{l}\text { Long segment coarctation, } \\
\text { large VSD }\end{array}$ & $\begin{array}{l}\text { Extreme preterm, low birth } \\
\text { weight }(1.4 \mathrm{~kg}) \text {, Down's syndrome }\end{array}$ & Large & $\begin{array}{l}\text { Normal } \\
\text { (good) }\end{array}$ & 5.8 & 3.2 & 2.3 & 1.7 \\
\hline Discrete coarctation & $\begin{array}{l}\text { Late referral, pulmonary hyper- } \\
\text { tension }\end{array}$ & Large & $\begin{array}{l}\text { Severe } \\
\text { (good) }\end{array}$ & 5.1 & 3.6 & 3.5 & 1.8 \\
\hline $\begin{array}{l}\text { Discrete coarctation, mild arch } \\
\text { hypoplasia, ASD, bicuspid aortic valve }\end{array}$ & $\begin{array}{l}\text { Premature, low body weight } \\
1.7 \mathrm{~kg} \text {. No response to } \mathrm{PGE}_{1}\end{array}$ & None & $\begin{array}{l}\text { Normal } \\
\text { (good) }\end{array}$ & 6.5 & 2.9 & 2.5 & 1.8 \\
\hline Discrete coarctation & No response to medical therapy & None & $\begin{array}{l}\text { Normal } \\
\text { (good) }\end{array}$ & 7.4 & 4.8 & 3.2 & 1.2 \\
\hline
\end{tabular}

$\mathrm{ASD}=$ atrial septal defect; $\mathrm{VSD}=$ ventricular septal defect; $\mathrm{PDA}=$ patent ductus arteriosus; $\mathrm{RV}$ = right ventricle; $\mathrm{RVH}=$ right ventricular hypertrophy; $\mathrm{AoV}=$ aortic valve; $A A$ = ascending aorta; $T A=$ transverse arch; $D=$ descending aorta; $S C D=$ sickle cell disease; $C L D=$ chronic lung disease; $R S V=$ respiratory syncytial virus; $\mathrm{PGE}_{1}=$ prostaglandin $\mathrm{E}_{1}$.

The clinical status improved in all patients. Echocardiographic assessment showed improvement in cardiac function. Mean urine output before intervention of all patients was $1.6 \mathrm{ml} / \mathrm{kg} /$ hour $(0.6-$ 2.7) which improved to $3.1 \mathrm{ml} / \mathrm{kg} / \mathrm{hour}(1.4-4.8 \mathrm{ml} /$ $\mathrm{kg} /$ hour) after dilatation. This improvement was statistically significant $(p<0.0001,95 \%$ confidence interval -2.1 to -0.93 ). Detailed results are presented in Table 1. 
Table 3: Catheterization data with outcome.

\begin{tabular}{llllll}
\hline PGB & PGA & Gradient drop & Transfusion & Heparin & Follow up \\
\hline 65 & 22 & 43 & None & None & Surgical repair \\
10 & 10 & No change in gradient & None & None & Surgical repair \\
47 & 28 & 19 & None & None & Surgical repair \\
40 & 40 & No change in gradient & None & Needed for 48 hrs. & Surgical repair \\
28 & 13 & 15 & None & None & Surgical repair \\
55 & 15 & 40 & None & Needed for 24 hrs. & Redilation \\
40 & 12 & 28 & Needed & Needed for 48 hrs. & Lost \\
22 & 0 & 22 & None & None & Redilation \\
48 & 20 & 28 & None & None & Surgical repair \\
10 & 6 & 4 & None & None & No recoarctaion \\
30 & 0 & 30 & Needed & None & Surgical repair \\
6 & 0 & 6 & None & None & Lost \\
30 & 10 & 20 & None & Needed for 48 hrs. & No recoarctaion \\
90 & 20 & 70 & None & None & No recoarctaion \\
\hline
\end{tabular}

PGB = pressure gradient before the percutaneous balloon angioplasty; PGA = pressure gradient after the percutaneous balloon angioplasty.

\section{Follow Up and Further Management}

The mean follow up time was 25 months (range 15-58 months). One month survival was $100 \%$, two year survival was $86 \%$ (two deaths, both not related to intervention). One patient died after 6 weeks of intervention due to $P$. aeruginosa and staphylococcal sepsis. The other died 13 months after intervention due to sickle cell crisis. Seven patients needed surgical repair due to recoarctation within a mean time of 12 weeks of intervention. Two patients needed redilation within 12 months of intervention. Three patients did not require any further intervention (follow up time: 15-31 months).

\section{Discussion}

The current paper presents the effectiveness of percutaneous balloon angioplasty in 14 patients with infantile aortic coarctation. All patients were considered for balloon angioplasty due to their multiple risk factors (Table 2) although surgical repair is the gold standard for this age group [13]. After percutaneous balloon angioplasty all infants showed significant clinical and hemodynamic improvement. No mortal- ity was recorded in relation to the procedure. However, as reported in other studies, the restenosis rate was high. These results confirm previous reports that demonstrate that percutaneous balloon angioplasty is effective for stabilizing patients and, in some cases, improving survival $[8,14]$.

Successful percutaneous balloon angioplasty for neonatal aortic coarctation was reported in the early eighties [3]. It was initially described to be effective in neonates with discrete coarctation and good clinical condition $[15,16]$. In the successive years, different authors have concluded that there is a prohibitive high incidence of recoarctation, especially in neonates $[6,7,17]$. Therefore, the role of angioplasty in this age group remained controversial [17]. Surgery remains the preferred choice for neonates and young infants, due to lower restenosis and aneurysmal rate as compared to percutaneous balloon angioplasty [18]. However morbidity as well as mortality has been reported to be higher in infants with poor preoperative clinical status, low cardiac output, associated cardiac lesions including long segment arch hypoplasia, additional systemic disease, and low body weight [19-22].

The dilemma arises when confronted with sick infants and those with associated general risk fac- 
tor, as found in our series. In these cases, probably percutaneous balloon angioplasty is an effective and temporary alternative to surgery in order to minimize the operative risk and prepare them for safer final management $[8,14]$. Other authors have proven the efficacy and safety of this treatment option in this category of infants [8, 14, 23]. Interestingly $35 \%$ of our patients did not require further surgical management.

At the time of intervention, our patients were relatively old (mean age 69 days). The main contributory reasons for this were prematurity (two patients), low birth weight (three patients), and late referral (seven patients). The patients with low birth weight needed time to achieve an acceptable weight in order to perform balloon angioplasty. Late referrals were those born in small rural hospitals where, unfortunately, there were fewer facilities and less experienced primary health care providers.

$P G E_{1}$ infusion is the primary medical management for stabilizing sick neonates with aortic coarctation [24-26]. This treatment option was not suitable for our patients as some referred late and some did not respond favorably to $\mathrm{PGE}_{1}$.

\section{Limitations of the Study}

The authors acknowledge that the major limitations of this study are its retrospective nature as well as the relatively small number of patients. On the other hand, this category of patients is rare and hence a prospective study will take considerable time. It would have been interesting to compare our population to a control group of infants with similar clinical presentation undergoing surgical repair. Our treatment option and the previous similar reports confirm safety and efficacy of this management. Thus, such a prospective study would be unethical.

\section{Conclusions}

Percutaneous balloon angioplasty of aortic coarctation is safe and effective for neonates and infants with low body weight and hemodynamic instability. The procedure is not only helpful for stabilization of the extremely ill patients but also provides a bridging for them until future surgical repair. It should be considered as an emergent palliative procedure in this particular group of patients where other treatment alternatives are more risky.

\section{Acknowledgements}

We acknowledge Ms. Penelope Swift BSN, RM, RGN, RSCN, nurse manager, Comprehensive Cancer Centre, King Fahad Medical City. Ms. Swift is a native English speaker who assisted us with language editing and correction.

\section{Conflict of Interest}

The authors have no conflicts of interest relevant to this publication.

\section{Comment on this Article or Ask a Question}

\section{References}

1. Nadas AS, Fyler DC. Pediatric Cardiology, 3rd Edition. Philadelphia: Saunders; 1972.

2. Keith JD, Rowe RD, Vlad P. Heart Disease in Infancy and Childhood, 3rd Edition. New York: Macmillan Publishers Limited; 1978.

3. Lababidi Z. Neonatal transluminal balloon coarctation angioplasty. Am Heart J. 1983;106:752-753. DOI: 10.1016/00028703(83)90098-4

4. Cowley CG, Orsmond GS, Feola P, McQuillan L, Shaddy RE. Longterm, randomized comparison of balloon angioplasty and surgery for native coarctation of the aorta in childhood. Circulation. 2005;111:
3453-3456. DOI: 10.1161/CIRCULATIONAHA.104.510198

5. Hernández-González $M$, Solorio $S$, Conde-Carmona I, Rangel-Abundis A, Ledesma M, Munayer J, et al. Intraluminal aortoplasty vs. surgical aortic resection in congenital aortic coarctation. A clinical random study in pediatric patients. Arch Med Res. 2003;34:305-310. DOI: 10.1016/S01884409(03)00055-9

6. Galal MO, Schmaltz AA, Joufan M, Benson $L$, Samatou L, Halees Z. Balloon dilation of native aortic coarctation in infancy. Z Kardiol. 2003;92:735-741. DOI: 10.1007/ s00392-003-0956-x
7. Redington AN, Booth $P$, Shore DF, Rigby ML. Primary balloon dilation of coarctation of the aorta in neonates. $\mathrm{Br}$ Heart J. 1990;64:277-281. DOI: 10.1136/ hrt.64.4.277

8. Doshi AR, Rao PS. Coarctation of aorta: management options and decision making. Pediatr Therapeut. 2012;5(6):1-10. DOI: 10.4172/2161-0665.s5-006

9. Salahuddin N, Wilson AD, Rao PS. An unusual presentation of coarctation of the aorta in infancy: role of balloon angioplasty in the critically ill infant. Am Heart J. 1991;122:1772-1775. DOI: 10.1016/00028703(91)90300-7 
10. Rao PS. Current status of balloon angioplasty for neonatal and infant aortic coarctation. Progress Pediatr Cardiol. 2001;14:35-44. DOI: 10.1016/S10589813(01)00114-X

11. Marvin WJ, Mahoney LT, Rose EF. Pathologic sequelae of balloon dilation angioplasty of unoperated coarctation of the aorta in children. J Am Coll Cardiol. 1986;7:117A.

12. Cooper RS, Ritter SB, Rothe WB, Chen CK, Griepp R, Golinko RJ. Angioplasty for coarctation of the aorta: long-term results. Circulation. 1987;75:600-604. DOI: 10.1161/01.CIR.75.3.600

13. Crafoord C, Nylin G. Congenital coarctation of the aorta and its surgical treatment. J Thorac Surg. 1945;14:347.

14. Bouzguenda I, Marini D, Ou P, Boudjemline $Y$, Bonnet D, Agnoletti G. Percutaneous treatment of neonatal aortic coarctation presenting with severe left ventricular dysfunction as a bridge to surgery. Cardiol Young. 2009;19:244-251. DOI: 10.1017/ S1047951109003837

15. Rao PS, Galal O, Smith PA, Wilson AD. Five- to nine-year follow-up results of balloon angioplasty of native aortic coarctation in infants and children. J Am Coll Cardiol. 1996;27:462470. DOI: 10.1016/0735-1097(95)00479-3

16. Patel HT, Madani A, Paris YM, Warner KG, Hijazi ZM. Balloon angioplasty of native coarctation of the aorta in infants and neonates: is it worth the hassle? Pediatr Cardiol. 2001;22:53-57. DOI: 10.1007/ s002460010153
17. Park Y, Lucas VW, Sklansky MS, Kashani IA, Rothman A. Balloon angioplasty of native aortic coarctation in infants 3 months of age and younger. Am Heart J. 1997;34:917-923. DOI: 10.1016/S00028703(97)80015-4

18. Fiore AC, Fischer LK, Schwartz T, Jureidini S, Balfour I, Carpenter D, et al. Comparison of angioplasty and surgery for neonatal aortic coarctation. Ann Thorac Surg. 2005;80:1659-1664. DOI: 10.1016/j.athoracsur.2005.03.143

19. Chang AC, Hanley FL, Lock JE, Castañeda AR, Wessel DL. Management and outcome of low birth weight neonates with congenital heart disease. J Pediatr. 1994;124:461-466. DOI: 10.1016/S00223476(94)70376-0

20. Rossi AF, Seiden HS, Sadeghi AM, Nguyen $\mathrm{KH}$, Quitana CS, Gross RP, et al. The outcome of cardiac operations in infants weighing two kilograms or less. J Thorac Cardiovasc Surg. 1998;116:28-35. DOI: 10.1016/S0022-5223(98)70239-9

21. Bacha EA, Almodovar M, Wessel DL. Surgery for coarctation of the aorta in infants weighing less than $2 \mathrm{~kg}$. Ann Thorac Surg. 2001;71:1260-1264. DOI: 10.1016/S00034975(00)02664-3

22. Quaegebeur JM, Jonas RA, Weinberg AD, Blackstone EH, Kirklin JW. Outcomes in seriously ill neonates with coarctation of the aorta: a multi-institutional study. J Thorac Cardiovasc Surg. 1994;108: 841-854.
23. Francis E, Gayathri S, Vaidyanathan B, Kannan BR, Kumar RK. Emergency balloon dilation or stenting of critical coarctation of the aorta in newborns and infants: an effective interim palliation. Ann Pediatr Cardiol. 2009;2:111-115. DOI: 10.4103/0974-2069.58311

24. Sidi D, Duval-Arnould M, Kachaner J, Villain E, Pedroni E, Piéchaud JF. Treatment by prostaglandin E1 of isolated coarctations in newborn infants with acute cardiac failure. Arch Fr Pediatr. 1987;44(1):21-25

25. Cheliakine-Chamboux C, Chantepie A, Godde F, Vaillant MC, Saliba E, Gold F, et al. Effects of PGE1 in neonatal aortic coarctation. Therapie. 1991;46(3): 231-233.

26. Liberman L, Gersony WM, Flynn PA, Lamberti JJ, Cooper RS, Stare TJ. Effectiveness of prostaglandin $\mathrm{E} 1$ in relieving obstruction in coarctation of the aorta without opening the ductus arteriosus. Pediatr Cardiol. 2004;25(1):49-52. DOI: 10.1007/ s00246-003-0549-5

Cite this article as: Jadoon S, Segaier, ME, Galal, MO. Percutaneous Balloon Angioplasty for Aortic Coarctation in Newborns and Infants. Structural Heart Disease. 2016;2(4):91-97. DOI: http:// dx.doi.org/10.12945/j.jshd.2016.005.15 